\title{
RILEM and the National Institute of Standards and Technology (NIST) over the past 50 years
}

\author{
E. J. Garboczi
}

Received: 7 September 2018/Accepted: 10 September 2018/Published online: 20 September 2018

(C) The Author(s) 2018, corrected publication 2019

\begin{abstract}
There has been a long partnership in the materials science of building materials between the National Institute of Standards and Technology (NIST) in the United States and the International Union of Laboratories and Experts in Construction Materials, Systems and Structures (RILEM). This paper discusses on the technical contributions NIST has made to RILEM, focusing on the articles published in Materials and Structures, whose 50-year anniversary is being celebrated in this issue. Since 1968, NIST has had a name change and a building materials division was formed, merged, and renamed since the 1970s, while RILEM has stayed constant in its name and organization, although its technical committee structure is purposely fluid. Many NIST personnel have contributed to the partnership between RILEM and NIST in more than one material type. This overview briefly covers these areas.
\end{abstract}

Keywords NIST · NBS · RILEM · Concrete · Roofing $\cdot$ Cement $\cdot$ Materials and Structures

Partial contribution of the National Institute of Standards and Technology—not subject to US copyright

E. J. Garboczi $(\bowtie)$

Applied Chemicals and Materials Division, National Institute of Standards and Technology, Boulder, CO 80305, USA

e-mail: edward.garboczi@nist.gov

\section{Introduction}

The National Bureau of Standards (NBS) was founded in 1901 in the United States, and became the National Institute of Standards and Technology (NIST) in 1987. As both NBS and NIST, there has been a long partnership with the International Union of Laboratories and Experts in Construction Materials, Systems and Structures (RILEM) in building materials for at least 50 years. However, since this is the 50th anniversary of the RILEM flagship journal, Materials and Structures (MS), this article will focus on technical contributions of NBS and NIST made via the pages of this journal. Therefore, the only references in this paper, except for one, will be to papers in MS. There have been many NBS/NIST personnel who have been in RILEM leadership positions, and many who have initiated, chaired, or served on RILEM committees. That involvement is mainly outside the scope of this article, though those matters may be touched on as they are relevant to Materials and Structures (MS).

Since almost the beginning of NBS, there has been pioneering work on cement and other building materials [1]. Through the 1950s, this was carried on, along with other construction-related topics, by the Building Technology Division. In 1960, cement testing became part of this division that was renamed the Building Research Division in 1961. Cement and concrete quickly became a main topic of the Division's work. In the 1970s, NBS finally formed the Building Materials 
Division to have a better administrative focus on the building materials work. The work of this Division mainly concentrated on cement and concrete and polymer coatings, with a subset of the latter being roofing materials, with the overall focus being durability and service life. This was due to the leaders of the Division, at first James Wright and later followed by Geoffrey Frohnsdorff. Geoffrey Frohnsdorff was the leader mainly responsible for this focus on service life measurement and prediction. He said to me after his retirement that his career had consisted of developing two good ideas, service life prediction and cement hydration modeling, with the rest being "signing bits of paper". He was a very modest man.

The "prediction" part of this focus led to the emphasis on computational modeling in cement and concrete, continuing to the present, along with a strong experimental effort in the materials science of cement and concrete. The roofing effort was strong in the 1970s through the 1990s, but had mainly ended by 2000. The polymer coating effort has been focused on service life prediction and continues to be world-class, but has not interacted much with RILEM, although Larry Masters did some work with RILEM committees in the 1970s to about 1990.

At its start, the Building Materials Division at first fell under the higher-level administrative unit called the Center for Building Technology. In the late 1980s, the Center for Building Technology merged with the Center for Fire Research to become the Building and Fire Research Laboratory. In the 2000s, the name was changed to the Engineering Laboratory. Through all these higher-level changes, the Building Materials Division eventually merged with the Structures Division at NIST to become the Materials and Construction Research Division, then went through one more name change to the present-day Materials and Structural Systems Division, under the Engineering Laboratory at NIST. The materials research work continued uninterrupted by these administrative changes.

Table 1 shows the permanent NIST personnel who have contributed to the partnership with RILEM over the past 50 years. Some of the people named in Table 1 have moved on to academia, where they made additional great research contributions, but in what follows, only research published while they were NIST employees is covered.

There have been many academic and industrial collaborators in the work of NIST as presented in
Table 1 List of NIST employees who have published in Materials and Structures

\begin{tabular}{lll}
\hline William Cullen & Hamlin Jennings & Kenneth Snyder \\
\hline James Wright & Paul Brown & Paul Stutzman \\
Geoffrey Frohnsdorff & Lawrence Kaetzel & Chiara Ferraris \\
Walter Rossiter, Jr & Lawrence Masters & Jeffrey Bullard \\
James Clifton & Edward Garboczi & Nicos Martys \\
Leslie Struble & Dale Bentz & Scott Jones \\
\hline
\end{tabular}

Materials and Structures. Some of their names can be found in all the references in this article. However, Table 2 is a partial (almost certainly partial due to the author's imperfect memory) list of the names of researchers who have made a long-term stay at NIST (more than a week or two) and contributed to the effort that was sometimes reported in MS. These include students, post-docs, academics on sabbatical, and those from governmental or industrial laboratories.

The rest of this article gives more specific information about NIST research that has appeared in the pages of Materials and Structures.

\section{Cement and concrete}

Three general areas of partnership with RILEM in the area of cement and concrete should be mentioned before moving on to the specific technical papers.

(1) The award that RILEM gives for outstanding young (below 40) researchers is called the L'Hermite Medal. Five winners of this medal have been intimately associated with NIST after receiving the medal. Edward Garboczi received his Medal in 1992 [2]. When Francois de Larrard spent a year at NIST starting in 1996, since he had received his Medal in 1989, there were two L'Hermite Medalists working at NIST at the same time. After Francois de Larrard left in 1997, Dale Bentz received his Medal in 1998 [3], so there were again two Medalists working at NIST, both permanent employees. Jacques Marchand, while he was on sabbatical at NIST during 1999-2000, received his L'Hermite Medal, so for a part of a year there were three L'Hermite Medalists working at NIST. In 2012, when Jason Weiss spent a year's sabbatical at 
Table 2 List of long-term visitors at NIST who have contributed to NIST research

\begin{tabular}{llll}
\hline Erik Schlangen & Sidney Diamond & James Pommersheim & David Lange \\
\hline Jacques Marchand & Francois de Larrard & J. Francis Young & Jason Weiss \\
Aaron Sakulovich & Joseph Biernacki & Pan Feng & Pietro Lura \\
Zhiwei Qian & Sinan Erdogan & Xiuping Feng & R. Tate Coverdale \\
Yang Lu & Rolands Cepuritis & Kai Lyu & \\
\hline
\end{tabular}

NIST, there were again three L'Hermite Medalists working at NIST. I believe only ETHZurich has had more L'Hermite Medalists active at the same time. Pietro Lura also spent time working at NIST but before receiving his L'Hermite Medal, so he would make a total of six L'Hermite Medal winners closely associated with NIST at some point in their careers.

(2) The NIST/ACBM Computer Modelling Workshop, started under the auspices of the US National Science Foundation-funded Center for Advanced Cement-Based Materials (ACBM) and continued by NIST after ACBM was disbanded, was advertised via RILEM. NonUS students who attended could receive some form of graduate credits or points through RILEM. Many students, academics, and government/industrial researchers from Europe and Latin America came to the Workshop from 1990 to the present day due to this promotion by RILEM. There have been many changes in the Workshop over that time, starting from all modeling to a more balanced computational/experimental approach and today focusing on materials characterization, which is an absolute necessity for successful modeling.

(3) The NIST Electronic Monograph, started in 1997 and continuing today [concrete.nist.gov/monograph], has served to send NIST materials science, computational and experimental, results out into the world. While statistics were being kept, there were about 10,000 unique URLs accessing the Monograph every month, from almost 100 countries. Part of this wide usage is certainly due to the many interactions with RILEM over the years.

The cement and concrete-related papers in MS from NBS/NIST cover many topics. Although there are single-author papers in the below list, most have at least two authors, indicating collaboration both within
NIST and with external partners. Suspension rheology [4-6] is discussed, using both experiments and computations. Various aspects of hydration/curing [7-12] are explored, again using both experiments and computations. Other topics from this same dual point of view include shrinkage [13-16], transport (ions, water, heat) [17-24], including probably the first use of Lattice Boltzmann computational methods to construction material application [22, 23], and durability/degradation [25-27].

Part of the unique contribution of NIST to the above topics was the emphasis on the fact that these complex problems of the complicated random porous composite called concrete would only be solved by experiments informing computations and computations motivating and helping to explain experimental results. This contribution is well-documented in these MS references. NIST also showed how some of the same particle modeling concepts that had been used successfully at the cement paste level, representing individual 3D particle shapes and creating random assemblages of many particles, could also be carried out at the mortar/concrete scale [28].

NIST introduced the cement concrete materials science field to percolation concepts [2], and a later paper showed the mature application of the concept [7]. It is clear from the references above that NIST did a lot of work on transport. The reason for this emphasis was because of the overall research theme at NIST of service life prediction of building materials. The degradation of concrete materials is dominated by degradation mechanisms that are mainly controlled by transport of water and ions through the concrete. This was also the reason for the emphasis on microstructure modeling and performance prediction, as this would give a basis for accelerating degradation phenomena via computation. 


\section{Roofing and other topics}

There are fewer papers in MS in categories other than cement and concrete, but there are some important topics. The degradation and durability of polymeric roofing materials, mainly in sheet form, was an important topic at NIST for several decades [29-34] and made NIST a national leader in this research, which was looked to by industry. A performance approach to measure the "quality" of roofing materials was discussed as far back as 1984 [33]. The idea of service life prediction of building materials was formulated and promoted, which, as was said before, motivated most of the work of the Building Materials Division (and its various aliases) [35-38]. Finally, expert systems and knowledge-based artificial intelligence (AI) systems were thought about for construction systems, which was far ahead of its time [39]. The explosive present-day growth of Building Information Modeling (BIM) and other knowledge-based computational systems applied to construction show the prescience of this approach, documented in the pages of Materials and Structures.

\section{Summary}

Most of the people listed in Table 1 have moved on, are retired, or are deceased. The current NIST group in cement and concrete has just seen, in 2018, two key retirements: Chiara Ferraris and Dale Bentz. Others who have been responsible for many of the MS papers listed in this article are getting close to retirement. It is hoped that a new generation of NIST scientists and engineers will carry on the research. If they do, they will find that the partnership with RILEM will continue to prove fruitful in promoting ideas, publishing research, and providing valuable collaborations.

Acknowledgements I thank Pietro Lura for inviting me to write this article, and I thank all my NIST collaborators over the past 30 years for their wonderful collaboration and comradeship as we pushed the boundaries of the materials science of building materials in the areas I have briefly outlined.

\section{Compliance with ethical standards}

Conflict of interest The author declares that he has no conflict of interest.
Open Access This article is distributed under the terms of the Creative Commons Attribution 4.0 International License (http:// creativecommons.org/licenses/by/4.0/), which permits use, duplication, adaptation, distribution and reproduction in any medium or format, as long as you give appropriate credit to the original author(s) and the source, provide a link to the Creative Commons license and indicate if changes were made.

\section{References}

1. Passaglia Elio, Beal Karma (1999) A unique institution: The National Bureau of Standards 1950-1969. US Department of Commerce, Gaithersburg

2. Garboczi EJ (1993) Computational materials science of cement-based materials. Mater Struct 26(4):191-195

3. Bentz DP (1999) Modelling cement microstructure: pixels, particles, and property prediction. Mater Struct 32(3):187-195

4. de Larrard F, Ferraris CF, Sedran T (1998) Fresh concrete: a Herschel-Bulkley material. Mater Struct 31(7):494-498

5. Flatt RJ, Ferraris CF (2002) Acoustophoretic characterization of cement suspensions. Mater Struct 35(9):541-549

6. Zhang Min-Hong, Ferraris Chiara F, Zhu Huaning, Picandet Vincent, Peltz Max A, Stutzman Paul, De Kee Daniel (2010) Measurement of yield stress for concentrated suspensions using a plate device. Mater Struct 43(1-2):47-62

7. Bentz DP (2007) Cement hydration: building bridges and dams at the microstructure level. Mater Struct 40(4):397-404

8. Bentz DP, Stutzman PE, Zunino F (2017) Low-temperature curing strength enhancement in cement-based materials containing limestone powder. Mater Struct 50:173

9. Aughenbaugh Katherine L, Chancey Ryan T, Stutzman Paul, Juenger Maria C, Fowler David W (2013) An examination of the reactivity of fly ash in cementitious pore solutions. Mater Struct 46(5):869-880

10. Taylor HFW, Barret P, Brown PW, Double DD, Frohnsdorff G, Johansen V, Ménétrier-Sorrentino D, Odler I, Parrott LJ, Pommersheim JM, Regourd M, Young JF (1984) The hydration of tricalcium silicate. Matériaux et Construction 17(6):457-468

11. Young JF, Barret P, Bezjak A, Brown PW, Double DD, Frohnsdorff G, Johansen V, Pommersheim JM, Ramachandran VS, Taylor HFW (1987) Mathematical modelling of hydration of cement: hydration of dicalcium silicate. Mater Struct 20(5):377-382

12. Bentz DP, Hansen KK, Madsen HD, Vallée F, Griesel EJ (2001) Drying/hydration in cement pastes during curing. Mater Struct 34(9):557-565

13. Bentz DP, Quenard DA, Baroghel-Bouny V, Garboczi EJ, Jennings HM (1995) Modelling drying shrinkage of cement paste and mortar part 1. Structural models from nanometres to millimetres. Mater Struct 28(8):450-458

14. Sakulich AR, Bentz DP (2013) Mitigation of autogenous shrinkage in alkali activated slag mortars by internal curing. Mater Struct 46(8):1355-1367

15. Alou F, Ferraris CF, Wittmann FH (1987) Etude expérimentale du retrait du béton. Mater Struct 20(5):323-333

16. Li Xiaodan, Grasley Zachary C, Bullard Jeffrey W, Garboczi Edward J (2017) Irreversible desiccation shrinkage of 
cement paste caused by cement grain dissolution and hydrate precipitation. Mater Struct 50:104

17. Bentz DP, Quenard DA, Kunzel HM, Baruchel J, Peyrin F, Martys NS, Garboczi EJ (2000) Microstructure and transport properties of porous building materials. II: three-dimensional X-ray tomographic studies. Mater Struct 33(3):147-153

18. Bentz DP, Garboczi EJ (1992) Modelling the leaching of calcium hydroxide from cement paste: effects on pore space percolation and diffusivity. Mater Struct 25(9):523-533

19. Quenard Daniel A, Ke Xu, Künzel Hartwig M, Bentz Dale P, Martys Nicos S (1998) Microstructure and transport properties of porous building materials. Mater Struct 31(5):317-324

20. Bentz DP (1073) Transient plane source measurements of the thermal properties of hydrating cement pastes. Mater Struct 2007:40

21. Lura Pietro, Bentz Dale P, Lange David A, Kovler Konstantin, Bentur Arnon, van Breugel Klaas (2006) Measurement of water transport from saturated pumice aggregates to hardening cement paste. Mater Struct 39(9):861-868

22. Martys NS (1999) Diffusion in partially-saturated porous materials. Mater Struct 32(8):555-562

23. Martys NS, Hagedorn JG (2002) Multiscale modeling of fluid transport in heterogeneous materials using discrete Boltzmann methods. Mater Struct 35(10):650-658

24. Samson E, Marchand J, Snyder KA (2003) Calculation of ionic diffusion coefficients on the basis of migration test results. Mater Struct 36(3):156-165

25. Bentz Dale P, Davis Jeffrey M, Peltz Max A, Snyder Kenneth A (2014) Influence of internal curing and viscosity modifiers on resistance to sulfate attack. Mater Struct 47(4):581-589

26. Wright JR, Frohnsdorff G (1985) Durability of building materials: durability research in the United States and the influence of RILEM on durability research. Mater Struct 18(3):205-214
27. Frohnsdorff G (1982) Second international conference on the durability of building materials and component: final report of the organizing committee. Matériaux et Construction 15(2):177-178

28. Qian Z, Garboczi EJ, Ye G, Schlangen E (2016) Anm: a geometrical model for the composite structure of mortar and concrete using real-shape particles. Mater Struct 49(1-2):149-158

29. Rossiter W (1998) Progress report for TC 166-RMS: roofing materials and systems. Mater Struct 31(3):158-161

30. Rossiter WJ Jr (1988) Further investigation of the effect of application parameters on adhesive-bonded seams of singleply roof membranes. Mater Struct 21(4):243-249

31. Cullen WC, Rossiter WJ Jr (1986) Elastomeric, thermoplastic and modified bitumen roofing: a summary technical report of CIB W.83 \& RILEM 75-SLR joint committee. Mater Struct 19(4):323-329

32. WJ Rossiter Jr (1998) Fourth international symposium on roofing technology. Mater Struct 31(7):499-502

33. Cullen WC (1984) A performance approach to quality roofing membranes. Matériaux et Construction 17(4):333-338

34. Cullen WC, Sneck T (1980) A final report of RILEM technical committee 27-EVS. Matériaux et Construction 13(4):323-331

35. Pommersheim J, Clifton J (1985) Prediction of concrete service-life. Mater Struct 18(1):21-30

36. Masters LW, Brandt E (1987) Prediction of service life of building materials and components. Mater Struct 20(1):55-77

37. Masters LW (1986) Prediction of service life of building materials and components. Mater Struct 19(6):417-422

38. Masters LW, Brandt E (1989) Systematic methodology for service life prediction of building materials and components. Mater Struct 22(5):385-392

39. Kaetzel LJ, Clifton JR (1995) Expert/knowledge based systems for materials in the construction industry: state-ofthe-art report. Mater Struct 28(3):160-174 